\title{
Does the Relationship between Accounting Disclosure and Bank Loan Contracts Vary with Borrower Characteristics? Evidence from Emerging Markets
}

\author{
Dekui Li \\ School of Management, Wuhan Yangtze Business University \\ 3, Huangjiawu West Road, Hongshan District, Wuhan, Hubei 430065, China \\ Tel: 86-27-88147108Ｅ-mail: jerryinkorea@gmail.com \\ Liang Song (Corresponding author) \\ School of Business and Economics, Michigan Technological University \\ 1400 Townsend Drive, Houghton, MI 49931, United States \\ Tel: 1-906-487-4368Ｅ-mail: liangs@mtu.edu
}

\begin{abstract}
Zhaoguo Zhang
School of Management, Huazhong University of Science and Technology 1037 Luoyu Road, Wuhan, Hubei 430065, China Tel: 86-27-62273783_E-mail: xuehai0225@126.com
\end{abstract}

Received: April 30, 2014 Accepted: June 23, $2014 \quad$ Published: June 23, 2014 doi:10.5296/ajfa.v6i1.5565 URL: http://dx.doi.org/10.5296/ajfa.v6i1.5565

\begin{abstract}
We examine how borrower characteristics affect the relationship between accounting disclosure and bank loan contracts in emerging economies. We find that the effects of accounting disclosure on bank loan contracting terms such as the loan size, the loan maturity, and the loan spread, are more significant for borrowers with smaller size, higher leverage, lower profitability, lower tangibility, less diversity, younger age, and less lending
\end{abstract}




\section{Macrothink

relationship. These results suggest that the relationship between accounting disclosure and bank loan contracting terms are more pronounced for firms with higher credit risk.

Keywords: Accounting disclosure, Bank loan contracts, Emerging markets 


\section{Introduction}

One stream of empirical studies have demonstrated that banks provide more favorable loan contracting terms such as larger loan size, longer loan maturity, and lower loan spread for borrowers with superior disclosure rankings (e.g., Armstrong et al., 2010; Hasan and Song, 2014; Mazumdar and Sengupta, 2005). Another stream of academic research has shown that borrower characteristics have a significant effect on bank loan contracting process because banks take into account of borrower characteristics as risk factors to determine the loan contract (e.g., Strahan, 1999). However, little attention has been paid to the interaction effects between accounting disclosure and borrower characteristics on bank loan contracts. In this paper, we try to fill this void by investigating whether the relationship between accounting disclosure and bank loan contracts vary with borrower characteristics in emerging markets.

When creditors are trying to make a loan to a firm, they have to evaluate the borrower's credit risk. However, one obstacle in this process is the information asymmetry problems between lenders and borrowers (Bharath et al. 2008; Diamond, 2004). Borrowers' superior accounting disclosure can alleviate this information asymmetry problem and this effect should be more significant for firms with higher risk because banks can better monitor well-disclosed borrowers (Botosan, 1997; Botosan and Plumlee, 2002; Mazumdar and Sengupta, 2005). Emerging economies provide a sound testing ground for this research question because there is not enough country-level investor protection compared with developed countries and banks should pay more attention to borrowers' characteristics and their accounting disclosure levels (Hasan and Song, 2014).

Employing a sample including eleven emerging economies, we find that the effects of accounting disclosure on bank loan contracting terms such as the loan size, the loan maturity, and the loan spread, are more pronounced for borrowers with smaller size, higher leverage, lower profitability, lower tangibility, less diversity, younger age, and less lending relationship. These results suggest that the relationship between accounting disclosure and bank loan contracting terms are more significant for firms with higher credit risk.

Our paper contributes to the existing literature by several ways. First, as mentioned before, the individual effects of accounting disclosure and borrower characteristics on bank loan contracting process have been examined extensively in the existing literature (e.g., Hasan and Song, 2014; Mazumdar and Sengupta, 2005; Strahan, 1999). We add to this strand of literature by showing how accounting disclosure and borrower characteristics interact to affect bank loan contracts. Thus, we provide a more comprehensive picture about the bank loan contracting process.

Second, the existing literature such as Bae and Goyal (2009) and Qian and Strahan (2007) have shown the influence of country-level factors on bank loan contracts. We contribute to this stream of literature by investigating how firm-level factors influence bank loan contracts. Thus, we have shown more determinants of financial contracts in the syndicated loan market.

Finally, the existing literature has investigated the effects of accounting disclosure and corporate governance on the syndicated loan market in emerging economies (e.g., Francis et 
al., 2012; Hasan and Song, 2014). We contribute to this strand of literature by examining how borrower characteristics influence the effects of accounting disclosure on bank loan contracts. Thus, we provide a more complete picture about the determinants of bank loan contracting process in emerging markets.

The rest of the paper is organized as follows: section 2 describes the hypotheses about the effects of borrower characteristics on the relationship between accounting disclosure and bank loan contracting terms. Section 3 presents the sample, variable construction, and summary statistics. Section 4 shows the methodology and results. The last section concludes.

\section{The Effects of Borrower Characteristics}

The existing literature has established that the information asymmetry problems between banks and borrowers are important determinants of bank loan contracting terms. For instance, Jappelli and Pagano (1993) argue that lenders would like to provide more credit if borrowers have a better information environment. Diamond (2004) shows that lenders reduce the loan maturity if borrowers are more opaque. Freixas and Rochet (1997) presents that information asymmetry problems between creditors and borrowers significantly influence the loan spread.

Borrowers' accounting disclosure can reduce banks' cost to obtain the useful information about borrowers (Mazumdar and Sengupta, 2005). Thus, banks should provide more favorable contracting terms when borrowers have superior disclosure rankings. For example, Hasan and Song (2014) have shown that well-disclosed borrowers obtain a better bank loan contracts such as larger amount, longer maturity, and lower spread in emerging markets.

\subsection{Company Size}

As argued in Strahan (1999), larger companies are more possible to generate stable cash flows to service the future debt payment compared with small ones. In addition, larger companies are more likely to survive the financial crisis because of their established reputation in the market. Thus, larger companies can obtain better bank loan contracting terms. Smaller companies have more credit risk and the influence of accounting disclosure on bank loan contracting terms should be more pronounced for companies with smaller size.

Hypothesis 1: The effects of accounting disclosure on bank loan contracting terms such as the loan size, the loan maturity, and the loan spread, are more significant for borrowers with smaller size.

\subsection{Company Leverage}

Companies with higher leverage are more likely to face future insolvency (Strahan, 1999). In addition, these companies are more likely to have moral hazard problems. For example, higher leverage companies have incentive to change low risk assets to high risk assets after they obtain a loan from a creditor. Thus, lower leverage companies can obtain better bank loan contracting terms. Higher leverage companies have more credit risk and the influence of accounting disclosure on bank loan contracting terms should be more pronounced for companies with higher leverage. 
Hypothesis 2: The effects of accounting disclosure on bank loan contracting terms such as the loan size, the loan maturity, and the loan spread, are more significant for borrowers with higher leverage.

\subsection{Company Profitability}

Companies with higher profitability are more likely to generate future cash flow to service the future debt payment (Strahan, 1999). Thus, companies with higher profitability can obtain better bank loan contracting terms. Companies with lower profitability are more risky and the effects of accounting disclosure on bank loan contracting terms should be more pronounced for companies with lower profitability.

Hypothesis 3: The effects of accounting disclosure on bank loan contracting terms such as the loan size, the loan maturity, and the loan spread, are more significant for borrowers with lower profitability.

\subsection{Company Tangibility}

Tangible assets can reduce firms' information asymmetry problems and can be used as collateral to obtain a loan (Strahan, 1999). Thus, companies with higher tangibility can obtain better bank loan contracting terms. Companies with lower tangibility have more credit risk and the influence of accounting disclosure on bank loan contracting terms should be more pronounced for companies with lower tangibility.

Hypothesis 4: The effects of accounting disclosure on bank loan contracting terms such as the loan size, the loan maturity, and the loan spread, are more significant for borrowers with lower tangibility.

\subsection{Company Diversity}

Diversification can reduce companies' risk because the cash flow for the future debt repayment can be generated by several separate business lines. Thus, companies with higher diversification can obtain better bank loan contracting terms. Companies with lower diversification have more credit risk and the influence of accounting disclosure on bank loan contracting terms should be more pronounced for companies with lower diversification.

Hypothesis 5: The effects of accounting disclosure on bank loan contracting terms such as the loan size, the loan maturity, and the loan spread, are more significant for borrowers with less diversity.

\subsection{Company Maturity}

Companies with a long history are more likely to have a good reputation in the capital market and are more competitive in their own industry. Thus, companies with a long history can obtain better bank loan contracting terms. Companies with a short history have more credit risk and the influence of accounting disclosure on bank loan contracting terms should be more pronounced for companies with younger age.

Hypothesis 6: The effects of accounting disclosure on bank loan contracting terms such as the 
loan size, the loan maturity, and the loan spread, are more significant for borrowers with younger age.

\subsection{Company Lending Relationship}

Companies with a longer lending relationship are more likely to have a less information asymmetry problem because banks are more familiar with these companies (Benston and Smith, 1976; Fama, 1985). Thus, companies with a long lending history can obtain better bank loan contracting terms. Companies with a short lending have more credit risk and the influence of accounting disclosure on bank loan contracting terms should be more pronounced for companies with less lending relationship.

Hypothesis 7: The effects of accounting disclosure on bank loan contracting terms such as the loan size, the loan maturity, and the loan spread, are more significant for borrowers with less lending relationship.

\section{Sample, Variable Construction, and Summary Statistics}

\subsection{Sample and Variable Construction}

Our sample period is from 2000 to 2007, which exclude the U.S. financial crisis period of 2008. Our sample covers 11 economies: Brazil, Chile, Hong Kong, India, South Korea, Malaysia, the Philippines, Singapore, South Africa, Taiwan, and Thailand. Our sample includes 436 loans for 103 firms.

Following the existing literature (e.g., Francis et al., 2012; Hasan and Song, 2014; Klapper and Love, 2004), we define the variable Company_Disclosure as the total value of the answers to the questions in the transparency category of the 2000 survey by Credit Lyonnais Securities Asia (CLSA). We construct the variable Company_Governance as the average value of the answers to the questions in the management discipline, independence, accountability, responsibility, and fairness categories of the 2000 CLSA survey.

Our borrower characteristics are from the Worldscope database and the company website. We define the variable Company_Size as the logarithm of total assets. The variable Size_Dummy is equal to one if a company has more than the median value of Company_Size and zero otherwise. We construct the variable Company_Leverage as total liability scaled by total assets. The variable Leverage_Dummy is equal to one if a company has more than the median value of Company_Leverage and zero otherwise. The variable Company_Profitability is defined as earnings scaled by total assets. The variable Profitability_Dummy is equal to one if a company has more than the median value of Company_Profitability and zero otherwise. We define the variable Company_Tangibility as PP\&E scaled by total assets. The variable Tangibility_Dummy is equal to one if a company has more than the median value of Company_Tangibility and zero otherwise. We construct the variable Company_Diversification, which is equal to one if a company has more than one segment and zero otherwise. The variable Diversification_Dummy is equal to one if Company_Diversification is equal to one and zero otherwise. The variable Company_Maturity is defined as the number of years since their IPO. The variable 
Maturity_Dummy is equal to one if a company has more than the median value of Company_ Maturity and zero otherwise. The variable Company_Lending_Relationship is defined as the logarithm of the sum between one and the number of previous borrowing. The variable Lending_Relationship_Dummy is equal to one if a company has more than the median value of Company_Lending_Relationship and zero otherwise.

The two country-level variables are constructed as the control variables. Specifically, the variable Country_Investor_Protection is defined as the average value of the world governance index. The variable Country_GDP_Growth is equal to Change in GDP per capita, which is from the World Development Indicator database.

Our bank loan variables are from the Dealscan database. Specifically, the variable Bank_Loan_Size is used to measure loan amount. The variable Bank_Loan_Spread is used to measure loan maturity. The variable Bank_Loan_Spread is used to measure loan spread. The variable Bank_Loan_Type_Dummy is a series of dummy variables for different types of loans such as term loans. The variable Industry_Dummy is a series of dummy variables for each industry. The variable Year_Dummy is a series of dummy variables for each year.

\subsection{Summary Statistics}

Table 1 presents the summary statistics of our variables. We report mean, standard deviation, 10th Percentile, 50th Percentile, and 90th Percentile in the table. The average bank loan size is $\$ 154.10$ million. The average loan maturity is 49.01 months. The mean value of loan spread is 137.01 basis points. The average GDP growth is $4.31 \%$. All the variables have significant variations as shown in the column of standard deviation. These descriptive statistics are consistent with the results reported in the previous literature.

Table 1. Summary Statistics

\begin{tabular}{|l|c|c|c|c|c|}
\hline & Mean & Standard & 10th & 50th & 90th \\
\hline & & Deviation & Percentile & Percentile & Percentile \\
\hline Company_Disclosure & 58.02 & 21.35 & 20.00 & 50.00 & 80.00 \\
\hline Company_Size & 16.90 & 2.66 & 14.54 & 17.25 & 22.25 \\
\hline Company_Leverage & 0.45 & 0.18 & 0.24 & 0.46 & 0.71 \\
\hline Company_Profitability & 0.51 & 0.44 & 0.15 & 0.41 & 0.90 \\
\hline Company_Tangibility & 0.48 & 0.25 & 0.10 & 0.51 & 0.74 \\
\hline Company_Diversification & 0.63 & 0.48 & 0.00 & 1.00 & 1.00 \\
\hline Company_Maturity & 11.65 & 4.04 & 4.00 & 10.00 & 16.00 \\
\hline Company_Lending_Relationship & 0.54 & 0.52 & 0.00 & 0.68 & 1.36 \\
\hline Conpany_Governance & 53.33 & 14.30 & 24.00 & 54.64 & 81.10 \\
\hline Country_Investor_Protection & 64.25 & 15.88 & 40.27 & 62.34 & 87.55 \\
\hline Country_GDP_Growth (\%) & 4.31 & 1.66 & 2.48 & 4.36 & 6.98 \\
\hline Bank_Loan_Size (\$ millions) & 154.10 & 20.33 & 130.10 & 151.23 & 183.99 \\
\hline Bank_Loan_Maturity (months) & 49.01 & 11.02 & 37.00 & 47.00 & 66.00 \\
\hline Bank_Loan_Spread (basis points) & 137.01 & 10.11 & 123.00 & 136.50 & 152.00 \\
\hline
\end{tabular}


The definitions of all variables are shown in the Appendix. We report mean, standard deviation, 10th Percentile, 50th Percentile, and 90th Percentile in the table.

\section{Methodology and Results}

\subsection{Methodology}

To examine the influence of borrower characteristics on the relationship between accounting disclosure and bank loan contracting terms, we estimate the following equation:

Bank loan contract terms $=\alpha+\beta_{1}$ Company_Disclosure $+\beta_{2}$ Company_Disclosure $*$
Borrower characteristics dummy $+\beta_{3}$ Control variables + Industry_Dummy + Year_Dummy $+\varepsilon$

where bank loan contract terms include Bank_Loan_Size, Bank_Loan_Maturity, and Bank_Loan_Spread. Borrower characteristics dummy include Size_Dummy, Leverage_Dummy, Profitability_Dummy, Tangibility_Dummy, Diversification_Dummy, Maturity_Dummy, and Lending_Relationship_Dummy. Our control variables include Company_Size, Company_Leverage, Company_Profitability, Company_Tangibility, Company_Diversification, Company_Maturity, Company_Lending_Relationship, Company_Governance, Country_Investor_Protection, and Country_GDP_Growth. Finally, we include Industry_Dummy and Year_Dummy. We cluster borrower-level when calculating standard errors.

\subsection{Results}

We present the results to examine the effects of company size on the relationship between accounting disclosure and bank loan contracting terms such as loan size, loan maturity, and loan spread in Table 2. In column 1, the effects of accounting disclosure on the loan size are equal to (0.0021-0.0006*Size_Dummy). The results suggest that the effects of accounting disclosure on the loan size are more significant for borrowers with smaller size. In column 2, the effects of accounting disclosure on the loan maturity are equal to (0.0028-0.0008*Size_Dummy). The results suggest that the effects of accounting disclosure on the loan maturity are more significant for borrowers with smaller size. In column 3 , the effects of accounting disclosure on the loan spread are equal to $(-0.0018+0.0006 *$ Size_Dummy). The results suggest that the effects of accounting disclosure on the loan spread are more significant for borrowers with smaller size. In summary, our results are consistent with Hypothesis 1 and the effects of accounting disclosure on bank loan contracting terms such as the loan size, the loan maturity, and the loan spread, are more significant for borrowers with smaller size. 
Table 2. Regressions of bank loan contracting terms on the interaction between Company_Disclosure and Size_Dummy

\begin{tabular}{|c|c|c|c|}
\hline & \multicolumn{3}{|c|}{ Dependent variable } \\
\hline & Log_Loan_Size & Log_Loan_Maturity & Log_Loan_Spread \\
\hline & $(1)$ & $(2)$ & (3) \\
\hline \multirow[t]{2}{*}{ Company_Disclosure } & $0.0021 * * *$ & $0.0028 * * *$ & $-0.0018 * * *$ \\
\hline & $(0.0003)$ & $(0.0006)$ & $(0.0002)$ \\
\hline \multicolumn{4}{|l|}{ Company_Disclosure* } \\
\hline \multirow[t]{2}{*}{ Size_Dummy } & $-0.0006 * * *$ & $-0.0008 * * *$ & $0.0006^{* * *}$ \\
\hline & $(0.0001)$ & $(0.0002)$ & $(0.0001)$ \\
\hline \multirow[t]{2}{*}{ Company_Size } & $0.0038 * * *$ & $0.0040 * * *$ & $-0.0039 * * *$ \\
\hline & $(0.0007)$ & $(0.0006)$ & $(0.0008)$ \\
\hline \multirow[t]{2}{*}{ Company_Leverage } & $-0.0555 * * *$ & $-0.1678 * * *$ & $0.0311 * * *$ \\
\hline & $(0.0095)$ & $(0.0289)$ & $(0.0055)$ \\
\hline \multirow[t]{2}{*}{ Company_Profitability } & $0.0149 * * *$ & $0.0379 * * *$ & $-0.0020 * * *$ \\
\hline & $(0.0028)$ & $(0.0072)$ & $(0.0003)$ \\
\hline \multirow[t]{2}{*}{ Company_Tangibility } & 0.0157 & 0.0339 & $-0.0827 * * *$ \\
\hline & $(0.0400)$ & $(0.0704)$ & $(0.0199)$ \\
\hline \multirow[t]{2}{*}{ Company__Diversification } & $0.0155 * * *$ & $0.0385 * * *$ & $-0.0023 * * *$ \\
\hline & $(0.0029)$ & $(0.0075)$ & $(0.0005)$ \\
\hline \multirow[t]{2}{*}{ Company_Maturity } & $0.0020 * * *$ & $0.0030 * * *$ & $-0.0028 * * *$ \\
\hline & $(0.0003)$ & $(0.0004)$ & $(0.0006)$ \\
\hline \multirow[t]{2}{*}{ Company_Lending_Relationship } & $0.0470 * * *$ & $0.0866 * * *$ & $-0.0489 * * *$ \\
\hline & $(0.0161)$ & $(0.0240)$ & $(0.0106)$ \\
\hline \multirow[t]{2}{*}{ Company_Governance } & $0.0038 * * *$ & $0.0081 * * *$ & $-0.0039 * * *$ \\
\hline & $(0.0009)$ & $(0.0010)$ & $(0.0006)$ \\
\hline \multirow[t]{2}{*}{ Country_Investor_Protection } & $0.0025 * * *$ & $0.0034 * * *$ & $-0.0017 * * *$ \\
\hline & $(0.0004)$ & $(0.0010)$ & $(0.0004)$ \\
\hline \multirow[t]{2}{*}{ Country_GDP_Growth } & 0.0052 & 0.0110 & -0.0143 \\
\hline & $(0.0056)$ & $(0.0109)$ & $(0.0096)$ \\
\hline \multicolumn{4}{|l|}{ Control For } \\
\hline Bank_Loan_Type_Dummy & Yes & Yes & Yes \\
\hline Industry_Dummy & Yes & Yes & Yes \\
\hline Year_Dummy & Yes & Yes & Yes \\
\hline Obs & 436 & 436 & 150 \\
\hline Adjusted $R^{2}$ & 0.5733 & 0.5790 & 0.6500 \\
\hline
\end{tabular}

The definitions of all variables are shown in the Appendix. We cluster at the borrower level when calculating standard errors. We report coefficients in the table and standard errors in the parentheses. We employ $*, * *$, and $* * *$ to indicate significance at the $10 \%, 5 \%$, and $1 \%$ levels respectively.

We show the results to investigate the effects of company leverage on the relationship 


\section{Macrothink}

between accounting disclosure and bank loan contracting terms such as loan size, loan maturity, and loan spread in Table 3. In column 1, the effects of accounting disclosure on the loan size are equal to $\left(0.0015+0.0005^{*}\right.$ Leverage_Dummy $)$. The results suggest that the effects of accounting disclosure on the loan size are more significant for borrowers with higher leverage. In column 2 , the effects of accounting disclosure on the loan maturity are equal to $(0.0020+0.0007 *$ Leverage_Dummy). The results suggest that the effects of accounting disclosure on the loan maturity are more significant for borrowers with higher leverage. In column 3, the effects of accounting disclosure on the loan spread are equal to $(-0.0012-0.0007 *$ Leverage_Dummy). The results suggest that the effects of accounting disclosure on the loan spread are more significant for borrowers with higher leverage. In summary, our results are consistent with Hypothesis 2 and the effects of accounting disclosure on bank loan contracting terms such as the loan size, the loan maturity, and the loan spread, are more significant for borrowers with higher leverage. 
Table 3. Regressions of bank loan contracting terms on the interaction between Company_Disclosure and Leverage_Dummy

\begin{tabular}{|c|c|c|c|}
\hline & \multicolumn{3}{|c|}{ Dependent variable } \\
\hline & Log_Loan_Size & Log_Loan_Maturity & Log_Loan_Spread \\
\hline & (1) & $(2)$ & (3) \\
\hline \multirow[t]{2}{*}{ Company_Disclosure } & $0.0015 * * *$ & $0.0020 * * *$ & $-0.0012 * * *$ \\
\hline & $(0.0004)$ & $(0.0005)$ & $(0.0003)$ \\
\hline \multicolumn{4}{|l|}{ Company_Disclosure* } \\
\hline \multirow[t]{2}{*}{ Leverage_Dummy } & $0.0005 * * *$ & $0.0007 * * *$ & $-0.0007 * * *$ \\
\hline & $(0.0001)$ & $(0.0001)$ & $(0.0001)$ \\
\hline \multirow[t]{2}{*}{ Company_Size } & $0.0037 * * *$ & $0.0041 * * *$ & $-0.0037 * * *$ \\
\hline & $(0.0006)$ & $(0.0007)$ & $(0.0009)$ \\
\hline \multirow[t]{2}{*}{ Company_Leverage } & $-0.0557 * * *$ & $-0.1670 * * *$ & $0.0318 * * *$ \\
\hline & $(0.0098)$ & $(0.0283)$ & $(0.0050)$ \\
\hline \multirow{2}{*}{ Company_Profitability } & $0.0147 * * *$ & $0.0370 * * *$ & $-0.0025 * * *$ \\
\hline & $(0.0029)$ & $(0.0079)$ & $(0.0005)$ \\
\hline \multirow[t]{2}{*}{ Company_Tangibility } & 0.0154 & 0.0332 & $-0.0821 * * *$ \\
\hline & $(0.0401)$ & $(0.0701)$ & $(0.0190)$ \\
\hline \multirow[t]{2}{*}{ Company__Diversification } & $0.0150 * * *$ & $0.0383 * * *$ & $-0.0024 * * *$ \\
\hline & $(0.0028)$ & $(0.0079)$ & $(0.0006)$ \\
\hline \multirow[t]{2}{*}{ Company_Maturity } & $0.0021 * * *$ & $0.0031 * * *$ & $-0.0027 * * *$ \\
\hline & $(0.0004)$ & $(0.0005)$ & $(0.0007)$ \\
\hline \multirow[t]{2}{*}{ Company_Lending_Relationship } & $0.0471 * * *$ & $0.0861 * * *$ & $-0.0485 * * *$ \\
\hline & $(0.0165)$ & $(0.0242)$ & $(0.0109)$ \\
\hline \multirow[t]{2}{*}{ Company_Governance } & $0.0037 * * *$ & $0.0080 * * *$ & $-0.0037 * * *$ \\
\hline & $(0.0008)$ & $(0.0015)$ & $(0.0007)$ \\
\hline \multirow[t]{2}{*}{ Country_Investor_Protection } & $0.0024 * * *$ & $0.0033 * * *$ & $-0.0016 * * *$ \\
\hline & $(0.0005)$ & $(0.0011)$ & $(0.0003)$ \\
\hline \multirow[t]{2}{*}{ Country_GDP_Growth } & 0.0051 & 0.0113 & -0.0141 \\
\hline & $(0.0054)$ & $(0.0108)$ & $(0.0098)$ \\
\hline \multicolumn{4}{|l|}{ Control For } \\
\hline Bank_Loan_Type_Dummy & Yes & Yes & Yes \\
\hline Industry_Dummy & Yes & Yes & Yes \\
\hline Year_Dummy & Yes & Yes & Yes \\
\hline Obs & 436 & 436 & 150 \\
\hline Adjusted $R^{2}$ & 0.5734 & 0.5791 & 0.6502 \\
\hline
\end{tabular}

The definitions of all variables are shown in the Appendix. We cluster at the borrower level when calculating standard errors. We report coefficients in the table and standard errors in the parentheses. We employ $*, * *$, and $* * *$ to indicate significance at the $10 \%, 5 \%$, and $1 \%$ levels respectively.

We presents the results to examine the influence of company profitability on the relationship 


\section{Macrothink}

Asian Journal of Finance \& Accounting ISSN 1946-052X 2014, Vol. 6, No. 1

between accounting disclosure and bank loan contracting terms such as loan size, loan maturity, and loan spread in Table 4. In column 1, the effects of accounting disclosure on the loan size are equal to $\left(0.0022-0.0007^{*}\right.$ Profitability_Dummy). The results imply that the effects of accounting disclosure on the loan size are more significant for borrowers with lower profitability. In column 2 , the effects of accounting disclosure on the loan maturity are equal to (0.0027-0.0007* Profitability_Dummy). The results suggest that the effects of accounting disclosure on the loan maturity are more significant for borrowers with lower profitability. In column 3, the effects of accounting disclosure on the loan spread are equal to $\left(-0.0019+0.0006^{*}\right.$ Profitability_Dummy). The results suggest that the effects of accounting disclosure on the loan spread are more significant for borrowers with lower profitability. In summary, our results are consistent with Hypothesis 3 and the effects of accounting disclosure on bank loan contracting terms such as the loan size, the loan maturity, and the loan spread, are more significant for borrowers with lower profitability. 
Table 4. Regressions of bank loan contracting terms on the interaction between Company_Disclosure and Profitability_Dummy

\begin{tabular}{|c|c|c|c|}
\hline & \multicolumn{3}{|c|}{ Dependent variable } \\
\hline & Log_Loan_Size & Log_Loan_Maturity & Log_Loan_Spread \\
\hline & (1) & $(2)$ & (3) \\
\hline \multirow{2}{*}{ Company_Disclosure } & $0.0022 * * *$ & $0.0027 * * *$ & $-0.0019 * * *$ \\
\hline & $(0.0002)$ & $(0.0005)$ & $(0.0003)$ \\
\hline \multirow{3}{*}{$\begin{array}{l}\text { Company_Disclosure* } \\
\text { Profitability_Dummy }\end{array}$} & & & \\
\hline & $-0.0007 * * *$ & $-0.0007 * * *$ & $0.0006^{* * *}$ \\
\hline & $(0.0001)$ & $(0.0001)$ & $(0.0001)$ \\
\hline \multirow[t]{2}{*}{ Company_Size } & $0.0039 * * *$ & $0.0041 * * *$ & $-0.0038^{* * *}$ \\
\hline & $(0.0006)$ & $(0.0005)$ & $(0.0006)$ \\
\hline \multirow[t]{2}{*}{ Company_Leverage } & $-0.0552 * * *$ & $-0.1673 * * *$ & $0.0310 * * *$ \\
\hline & $(0.0091)$ & $(0.0280)$ & $(0.0051)$ \\
\hline \multirow[t]{2}{*}{ Company_Profitability } & $0.0146 * * *$ & $0.0375 * * *$ & $-0.0022 * * *$ \\
\hline & $(0.0024)$ & $(0.0070)$ & $(0.0004)$ \\
\hline \multirow[t]{2}{*}{ Company_Tangibility } & 0.0154 & 0.0331 & $-0.0822 * * *$ \\
\hline & $(0.0401)$ & $(0.0700)$ & $(0.0193)$ \\
\hline \multirow[t]{2}{*}{ Company__Diversification } & $0.0152 * * *$ & $0.0388 * * *$ & $-0.0021 * * *$ \\
\hline & $(0.0023)$ & $(0.0078)$ & $(0.0004)$ \\
\hline \multirow[t]{2}{*}{ Company_Maturity } & $0.0021 * * *$ & $0.0032 * * *$ & $-0.0029 * * *$ \\
\hline & $(0.0002)$ & $(0.0004)$ & $(0.0005)$ \\
\hline \multirow[t]{2}{*}{ Company_Lending_Relationship } & $0.0472 * * *$ & $0.0864 * * *$ & $-0.0488 * * *$ \\
\hline & $(0.0160)$ & $(0.0241)$ & $(0.0102)$ \\
\hline \multirow[t]{2}{*}{ Company_Governance } & $0.0039 * * *$ & $0.0080 * * *$ & $-0.0038 * * *$ \\
\hline & $(0.0008)$ & $(0.0011)$ & $(0.0007)$ \\
\hline \multirow[t]{2}{*}{ Country_Investor_Protection } & $0.0026 * * *$ & $0.0035 * * *$ & $-0.0016^{* * *}$ \\
\hline & $(0.0005)$ & $(0.0009)$ & $(0.0003)$ \\
\hline \multirow[t]{2}{*}{ Country_GDP_Growth } & 0.0051 & 0.0113 & -0.0149 \\
\hline & $(0.0059)$ & $(0.0100)$ & $(0.0090)$ \\
\hline \multicolumn{4}{|l|}{ Control For } \\
\hline Bank_Loan_Type_Dummy & Yes & Yes & Yes \\
\hline Industry_Dummy & Yes & Yes & Yes \\
\hline Year_Dummy & Yes & Yes & Yes \\
\hline Obs & 436 & 436 & 150 \\
\hline Adjusted $R^{2}$ & 0.5731 & 0.5792 & 0.6504 \\
\hline
\end{tabular}

The definitions of all variables are shown in the Appendix. We cluster at the borrower level when calculating standard errors. We report coefficients in the table and standard errors in the parentheses. We employ $*, * *$, and $* * *$ to indicate significance at the $10 \%, 5 \%$, and $1 \%$ levels respectively. 


\section{Macrothink}

We presents the results to examine the effects of company tangibility on the relationship between accounting disclosure and bank loan contracting terms such as loan size, loan maturity, and loan spread in Table 5. In column 1, the effects of accounting disclosure on the loan size are equal to (0.0021-0.0006*Tangibility_Dummy). The results suggest that the effects of accounting disclosure on the loan size are more significant for borrowers with lower tangibility. In column 2 , the effects of accounting disclosure on the loan maturity are equal to (0.0026-0.0006*Tangibility_Dummy). The results suggest that the effects of accounting disclosure on the loan maturity are more significant for borrowers with lower tangibility. In column 3, the effects of accounting disclosure on the loan spread are equal to $\left(-0.0020+0.0005^{*}\right.$ Tangibility_Dummy). The results suggest that the effects of accounting disclosure on the loan spread are more significant for borrowers with lower tangibility. In summary, our results are consistent with Hypothesis 4 and the effects of accounting disclosure on bank loan contracting terms such as the loan size, the loan maturity, and the loan spread, are more significant for borrowers with lower tangibility. 
Table 5. Regressions of bank loan contracting terms on the interaction between Company_Disclosure and Tangibility_Dummy

\begin{tabular}{|c|c|c|c|}
\hline & \multicolumn{3}{|c|}{ Dependent variable } \\
\hline & Log_Loan_Size & Log_Loan_Maturity & Log_Loan_Spread \\
\hline & (1) & (2) & (3) \\
\hline \multirow[t]{2}{*}{ Company_Disclosure } & $0.0021 * * *$ & $0.0026 * * *$ & $-0.0020 * * *$ \\
\hline & $(0.0003)$ & $(0.0004)$ & $(0.0004)$ \\
\hline \multirow[t]{2}{*}{$\begin{array}{l}\text { Company_Disclosure* } \\
\text { Tangibility_Dummy }\end{array}$} & $-0.0006 * * *$ & $-0.0006 * * *$ & $0.0005 * * *$ \\
\hline & $(0.0001)$ & $(0.0001)$ & $(0.0001)$ \\
\hline \multirow[t]{2}{*}{ Company_Size } & $0.0037 * * *$ & $0.0040 * * *$ & $-0.0036^{* * *}$ \\
\hline & $(0.0005)$ & $(0.0005)$ & $(0.0005)$ \\
\hline \multirow[t]{2}{*}{ Company_Leverage } & $-0.0554 * * *$ & $-0.1677 * * *$ & $0.0312 * * *$ \\
\hline & $(0.0090)$ & $(0.0281)$ & $(0.0052)$ \\
\hline \multirow[t]{2}{*}{ Company_Profitability } & $0.0148 * * *$ & $0.0378 * * *$ & $-0.0023 * * *$ \\
\hline & $(0.0026)$ & $(0.0075)$ & $(0.0005)$ \\
\hline \multirow[t]{2}{*}{ Company_Tangibility } & 0.0150 & 0.0335 & $-0.0820 * * *$ \\
\hline & $(0.0400)$ & $(0.0709)$ & $(0.0190)$ \\
\hline \multirow[t]{2}{*}{ Company__Diversification } & $0.0154 * * *$ & $0.0389 * * *$ & $-0.0023 * * *$ \\
\hline & $(0.0024)$ & $(0.0079)$ & $(0.0005)$ \\
\hline \multirow[t]{2}{*}{ Company_Maturity } & $0.0022 * * *$ & $0.0032 * * *$ & $-0.0028 * * *$ \\
\hline & $(0.0003)$ & $(0.0005)$ & $(0.0006)$ \\
\hline \multirow[t]{2}{*}{ Company_Lending_Relationship } & $0.0470 * * *$ & $0.0866^{* * *}$ & $-0.0489 * * *$ \\
\hline & $(0.0160)$ & $(0.0241)$ & $(0.0102)$ \\
\hline \multirow[t]{2}{*}{ Company_Governance } & $0.0037 * * *$ & $0.0087 * * *$ & $-0.0039 * * *$ \\
\hline & $(0.0007)$ & $(0.0012)$ & $(0.0008)$ \\
\hline \multirow[t]{2}{*}{ Country_Investor_Protection } & $0.0025 * * *$ & $0.0034 * * *$ & $-0.0015 * * *$ \\
\hline & $(0.0004)$ & $(0.0007)$ & $(0.0002)$ \\
\hline \multirow[t]{2}{*}{ Country_GDP_Growth } & 0.0050 & 0.0119 & -0.0148 \\
\hline & $(0.0079)$ & $(0.0109)$ & $(0.0096)$ \\
\hline \multicolumn{4}{|l|}{ Control For } \\
\hline Bank_Loan_Type_Dummy & Yes & Yes & Yes \\
\hline Industry_Dummy & Yes & Yes & Yes \\
\hline Year_Dummy & Yes & Yes & Yes \\
\hline Obs & 436 & 436 & 150 \\
\hline Adjusted $R^{2}$ & 0.5739 & 0.5799 & 0.6509 \\
\hline
\end{tabular}

The definitions of all variables are shown in the Appendix. We cluster at the borrower level when calculating standard errors. We report coefficients in the table and standard errors in the parentheses. We employ $*, * *$, and $* * *$ to indicate significance at the $10 \%, 5 \%$, and $1 \%$ levels respectively.

We show the results to examine the effects of company diversification on the relationship 
between accounting disclosure and bank loan contracting terms such as loan size, loan maturity, and loan spread in Table 6 . In column 1, the effects of accounting disclosure on the loan size are equal to $\left(0.0020-0.0005^{*}\right.$ Diversification_Dummy). The results suggest that the effects of accounting disclosure on the loan size are more significant for borrowers with lower diversification. In column 2 , the effects of accounting disclosure on the loan maturity are equal to (0.0025-0.0005*Diversification_Dummy). The results suggest that the effects of accounting disclosure on the loan maturity are more significant for borrowers with lower diversification. In column 3 , the effects of accounting disclosure on the loan spread are equal to $\left(-0.0021+0.0004^{*}\right.$ Diversification_Dummy). The results suggest that the effects of accounting disclosure on the loan spread are more significant for borrowers with lower diversification. In summary, our results are consistent with Hypothesis 5 and the effects of accounting disclosure on bank loan contracting terms such as the loan size, the loan maturity, and the loan spread, are more significant for borrowers with lower diversification. 
Table 6. Regressions of bank loan contracting terms on the interaction between Company_Disclosure and Diversification_Dummy

\begin{tabular}{|c|c|c|c|}
\hline & \multicolumn{3}{|c|}{ Dependent variable } \\
\hline & Log_Loan_Size & Log_Loan_Maturity & Log_Loan_Spread \\
\hline & (1) & $(2)$ & (3) \\
\hline \multirow[t]{2}{*}{ Company_Disclosure } & $0.0020 * * *$ & $0.0025 * * *$ & $-0.0021 * * *$ \\
\hline & $(0.0004)$ & $(0.0003)$ & $(0.0005)$ \\
\hline \multicolumn{4}{|l|}{ Company_Disclosure* } \\
\hline \multirow[t]{2}{*}{ Diversification_Dummy } & $-0.0005 * * *$ & $-0.0005 * * *$ & $0.0004 * * *$ \\
\hline & $(0.0001)$ & $(0.0001)$ & $(0.0001)$ \\
\hline \multirow[t]{2}{*}{ Company_Size } & $0.0035 * * *$ & $0.0041 * * *$ & $-0.0037 * * *$ \\
\hline & $(0.0004)$ & $(0.0006)$ & $(0.0004)$ \\
\hline \multirow[t]{2}{*}{ Company_Leverage } & $-0.0553 * * *$ & $-0.1675 * * *$ & $0.0314 * * *$ \\
\hline & $(0.0096)$ & $(0.0280)$ & $(0.0050)$ \\
\hline \multirow{2}{*}{ Company_Profitability } & $0.0149 * * *$ & $0.0379 * * *$ & $-0.0024 * * *$ \\
\hline & $(0.0025)$ & $(0.0073)$ & $(0.0004)$ \\
\hline \multirow[t]{2}{*}{ Company_Tangibility } & 0.0151 & 0.0336 & $-0.0821 * * *$ \\
\hline & $(0.0401)$ & $(0.0710)$ & $(0.0197)$ \\
\hline \multirow[t]{2}{*}{ Company__Diversification } & $0.0158 * * *$ & $0.0383 * * *$ & $-0.0022 * * *$ \\
\hline & $(0.0022)$ & $(0.0075)$ & $(0.0004)$ \\
\hline \multirow[t]{2}{*}{ Company_Maturity } & $0.0023 * * *$ & $0.0034 * * *$ & $-0.0029 * * *$ \\
\hline & $(0.0004)$ & $(0.0006)$ & $(0.0007)$ \\
\hline \multirow[t]{2}{*}{ Company_Lending_Relationship } & $0.0472 * * *$ & $0.0868 * * *$ & $-0.0485 * * *$ \\
\hline & $(0.0162)$ & $(0.0225)$ & $(0.0112)$ \\
\hline \multirow[t]{2}{*}{ Company_Governance } & $0.0036^{* * *}$ & $0.0085 * * *$ & $-0.0036 * * *$ \\
\hline & $(0.0006)$ & $(0.0015)$ & $(0.0009)$ \\
\hline \multirow[t]{2}{*}{ Country_Investor_Protection } & $0.0026 * * *$ & $0.0032 * * *$ & $-0.0014 * * *$ \\
\hline & $(0.0005)$ & $(0.0007)$ & $(0.0003)$ \\
\hline \multirow[t]{2}{*}{ Country_GDP_Growth } & 0.0053 & 0.0110 & -0.0140 \\
\hline & $(0.0099)$ & $(0.0129)$ & $(0.0099)$ \\
\hline \multicolumn{4}{|l|}{ Control For } \\
\hline Bank_Loan_Type_Dummy & Yes & Yes & Yes \\
\hline Industry_Dummy & Yes & Yes & Yes \\
\hline Year_Dummy & Yes & Yes & Yes \\
\hline Obs & 436 & 436 & 150 \\
\hline Adjusted $R^{2}$ & 0.5731 & 0.5791 & 0.6501 \\
\hline
\end{tabular}

The definitions of all variables are shown in the Appendix. We cluster at the borrower level when calculating standard errors. We report coefficients in the table and standard errors in the parentheses. We employ $*, * *$, and $* * *$ to indicate significance at the $10 \%, 5 \%$, and $1 \%$ levels respectively.

We presents the results to examine the effects of company maturity on the relationship 


\section{Macrothink}

Asian Journal of Finance \& Accounting ISSN 1946-052X 2014, Vol. 6, No. 1

between accounting disclosure and bank loan contracting terms such as loan size, loan maturity, and loan spread in Table 7. In column 1, the effects of accounting disclosure on the loan size are equal to (0.0023-0.0006*Maturity_Dummy). The results suggest that the effects of accounting disclosure on the loan size are more significant for borrowers with lower maturity. In column 2, the effects of accounting disclosure on the loan maturity are equal to (0.0027-0.0006*Maturity_Dummy). The results suggest that the effects of accounting disclosure on the loan maturity are more significant for borrowers with lower maturity. In column 3, the effects of accounting disclosure on the loan spread are equal to $\left(-0.0023+0.0005^{*}\right.$ Maturity_Dummy). The results suggest that the effects of accounting disclosure on the loan spread are more significant for borrowers with lower maturity. In summary, our results are consistent with Hypothesis 6 and the effects of accounting disclosure on bank loan contracting terms such as the loan size, the loan maturity, and the loan spread, are more significant for borrowers with lower maturity. 
Table 7. Regressions of bank loan contracting terms on the interaction between Company_Disclosure and Maturity_Dummy

\begin{tabular}{|c|c|c|c|}
\hline & \multicolumn{3}{|c|}{ Dependent variable } \\
\hline & Log_Loan_Size & Log_Loan_Maturity & Log_Loan_Spread \\
\hline & (1) & $(2)$ & (3) \\
\hline \multirow[t]{2}{*}{ Company_Disclosure } & $0.0023 * * *$ & $0.0027 * * *$ & $-0.0023 * * *$ \\
\hline & $(0.0005)$ & $(0.0004)$ & $(0.0005)$ \\
\hline \multicolumn{4}{|l|}{ Company_Disclosure* } \\
\hline \multirow[t]{2}{*}{ Maturity_Dummy } & $-0.0006 * * *$ & $-0.0006 * * *$ & $0.0005 * * *$ \\
\hline & $(0.0001)$ & $(0.0001)$ & $(0.0001)$ \\
\hline \multirow[t]{2}{*}{ Company_Size } & $0.0037 * * *$ & $0.0043 * * *$ & $-0.0039 * * *$ \\
\hline & $(0.0005)$ & $(0.0007)$ & $(0.0005)$ \\
\hline \multirow[t]{2}{*}{ Company_Leverage } & $-0.0555 * * *$ & $-0.1677 * * *$ & $0.0316^{* * *}$ \\
\hline & $(0.0097)$ & $(0.0281)$ & $(0.0051)$ \\
\hline \multirow[t]{2}{*}{ Company_Profitability } & $0.0148 * * *$ & $0.0377 * * *$ & $-0.0026 * * *$ \\
\hline & $(0.0027)$ & $(0.0075)$ & $(0.0005)$ \\
\hline \multirow[t]{2}{*}{ Company_Tangibility } & 0.0150 & 0.0338 & $-0.0823 * * *$ \\
\hline & $(0.0407)$ & $(0.0716)$ & $(0.0199)$ \\
\hline \multirow[t]{2}{*}{ Company_Diversification } & $0.0159 * * *$ & $0.0385 * * *$ & $-0.0025 * * *$ \\
\hline & $(0.0024)$ & $(0.0078)$ & $(0.0004)$ \\
\hline \multirow[t]{2}{*}{ Company_Maturity } & $0.0025 * * *$ & $0.0036 * * *$ & $-0.0028 * * *$ \\
\hline & $(0.0005)$ & $(0.0007)$ & $(0.0006)$ \\
\hline \multirow[t]{2}{*}{ Company_Lending_Relationship } & $0.0474 * * *$ & $0.0867 * * *$ & $-0.0487 * * *$ \\
\hline & $(0.0164)$ & $(0.0227)$ & $(0.0114)$ \\
\hline \multirow[t]{2}{*}{ Company_Governance } & $0.0037 * * *$ & $0.0086^{* * *}$ & $-0.0037 * * *$ \\
\hline & $(0.0007)$ & $(0.0016)$ & $(0.0010)$ \\
\hline \multirow[t]{2}{*}{ Country_Investor_Protection } & $0.0024 * * *$ & $0.0030 * * *$ & $-0.0012 * * *$ \\
\hline & $(0.0004)$ & $(0.0006)$ & $(0.0002)$ \\
\hline \multirow[t]{2}{*}{ Country_GDP_Growth } & 0.0055 & 0.0112 & -0.0144 \\
\hline & $(0.0090)$ & $(0.0120)$ & $(0.0090)$ \\
\hline \multicolumn{4}{|l|}{ Control For } \\
\hline Bank_Loan_Type_Dummy & Yes & Yes & Yes \\
\hline Industry_Dummy & Yes & Yes & Yes \\
\hline Year_Dummy & Yes & Yes & Yes \\
\hline Obs & 436 & 436 & 150 \\
\hline Adjusted $R^{2}$ & 0.5725 & 0.5788 & 0.6510 \\
\hline
\end{tabular}

The definitions of all variables are shown in the Appendix. We cluster at the borrower level when calculating standard errors. We report coefficients in the table and standard errors in the parentheses. We employ $*, * *$, and $* * *$ to indicate significance at the $10 \%, 5 \%$, and $1 \%$ levels respectively.

We show the results to examine the effects of company previous lending relationship on the 


\section{Macrothink}

relationship between accounting disclosure and bank loan contracting terms such as loan size, loan maturity, and loan spread in Table 8. In column 1, the effects of accounting disclosure on the loan size are equal to $\left(0.0022-0.0007^{*}\right.$ Lending_Relationship_Dummy). The results suggest that the effects of accounting disclosure on the loan size are more significant for borrowers with less lending relationship. In column 2, the effects of accounting disclosure on the loan maturity are equal to $\left(0.0025-0.0007^{*}\right.$ Lending_Relationship_Dummy). The results suggest that the effects of accounting disclosure on the loan maturity are more significant for borrowers with less lending relationship. In column 3, the effects of accounting disclosure on the loan spread are equal to $\left(-0.0021+0.0006^{*}\right.$ Lending_Relationship_Dummy). The results suggest that the effects of accounting disclosure on the loan spread are more significant for borrowers with less lending relationship. In summary, our results are consistent with Hypothesis 7 and the effects of accounting disclosure on bank loan contracting terms such as the loan size, the loan maturity, and the loan spread, are more significant for borrowers with less lending relationship. 


\section{Macrothink}

Asian Journal of Finance \& Accounting ISSN 1946-052X 2014, Vol. 6, No. 1

Table 8. Regressions of bank loan contracting terms on the interaction between Company_Disclosure and Lending_Relationship_Dummy

\begin{tabular}{|c|c|c|c|}
\hline & \multicolumn{3}{|c|}{ Dependent variable } \\
\hline & Log_Loan_Size & $\begin{array}{c}\text { Log_Loan_Maturit } \\
y\end{array}$ & $\underset{d}{L o g \_L o a n \_S p r e a}$ \\
\hline & (1) & (2) & (3) \\
\hline \multirow[t]{2}{*}{ Company_Disclosure } & $0.0022 * * *$ & $0.0025 * * *$ & $-0.0021 * * *$ \\
\hline & $(0.0004)$ & $(0.0005)$ & $(0.0005)$ \\
\hline \multirow[t]{2}{*}{$\begin{array}{l}\text { Company_Disclosure* } \\
\text { Lending_Relationship_Dummy }\end{array}$} & $-0.0007 * * *$ & $-0.0007 * * *$ & $0.0006 * * *$ \\
\hline & $(0.0001)$ & $(0.0001)$ & $(0.0001)$ \\
\hline \multirow[t]{2}{*}{ Company_Size } & $0.0039 * * *$ & $0.0041 * * *$ & $-0.0038 * * *$ \\
\hline & $(0.0006)$ & $(0.0008)$ & $(0.0006)$ \\
\hline \multirow[t]{2}{*}{ Company_Leverage } & $-0.0551 * * *$ & $-0.1671 * * *$ & $0.0311 * * *$ \\
\hline & $(0.0098)$ & $(0.0282)$ & $(0.0057)$ \\
\hline \multirow[t]{2}{*}{ Company_Profitability } & $0.0145 * * *$ & $0.0375 * * *$ & $-0.0025 * * *$ \\
\hline & $(0.0029)$ & $(0.0077)$ & $(0.0004)$ \\
\hline \multirow[t]{2}{*}{ Company_Tangibility } & 0.0152 & 0.0335 & $-0.0825 * * *$ \\
\hline & $(0.0402)$ & $(0.0712)$ & $(0.0195)$ \\
\hline \multirow[t]{2}{*}{ Company_Diversification } & $0.0156^{* * *}$ & $0.0381 * * *$ & $-0.0022 * * *$ \\
\hline & $(0.0026)$ & $(0.0074)$ & $(0.0004)$ \\
\hline \multirow[t]{2}{*}{ Company_Maturity } & $0.0027 * * *$ & $0.0038 * * *$ & $-0.0026 * * *$ \\
\hline & $(0.0006)$ & $(0.0008)$ & $(0.0005)$ \\
\hline \multirow[t]{2}{*}{ Company_Lending_Relationship } & $0.0476^{* * *}$ & $0.0865 * * *$ & $-0.0485 * * *$ \\
\hline & $(0.0163)$ & $(0.0229)$ & $(0.0116)$ \\
\hline \multirow[t]{2}{*}{ Conpany_Governance } & $0.0035 * * *$ & $0.0084 * * *$ & $-0.0039 * * *$ \\
\hline & $(0.0006)$ & $(0.0018)$ & $(0.0008)$ \\
\hline \multirow[t]{2}{*}{ Country_Investor_Protection } & $0.0023 * * *$ & $0.0031 * * *$ & $-0.0013 * * *$ \\
\hline & $(0.0005)$ & $(0.0007)$ & $(0.0003)$ \\
\hline \multirow[t]{2}{*}{ Country_GDP_Growth } & 0.0054 & 0.0110 & -0.0142 \\
\hline & $(0.0094)$ & $(0.0122)$ & $(0.0092)$ \\
\hline \multicolumn{4}{|l|}{ Control For } \\
\hline Bank_Loan_Type_Dummy & Yes & Yes & Yes \\
\hline Industry_Dummy & Yes & Yes & Yes \\
\hline Year_Dummy & Yes & Yes & Yes \\
\hline Obs & 436 & 436 & 150 \\
\hline Adjusted $R^{2}$ & 0.5734 & 0.5790 & 0.6519 \\
\hline
\end{tabular}

The definitions of all variables are shown in the Appendix. We cluster at the borrower level when calculating standard errors. We report coefficients in the table and standard errors in the parentheses. We employ $*, * *$, and $* * *$ to indicate significance at the $10 \%, 5 \%$, and $1 \%$ levels respectively. 


\section{Conclusion}

In this paper, we investigate how borrower characteristics affect the relationship between accounting disclosure and bank loan contracts in emerging economies. The evidence shows that the effects of accounting disclosure on bank loan contracting terms such as the loan size, the loan maturity, and the loan spread, are more significant for borrowers with smaller size, higher leverage, lower profitability, lower tangibility, less diversity, younger age, and less lending relationship. These results imply that the relationship between accounting disclosure and bank loan contracting terms are more pronounced for firms with higher credit risk.

One caveat is that the Dealscan database only includes large firms and we leave it in the future research. Our results also have some policy implications for policy makers. Specifically, to increase firms' access to the capital market, it is better to increase firms' disclosure level, which is more important for firms with higher risk.

\section{References}

Armstrong, C. S., Guay, W. R., \& Weber, J. P. (2010). The role of information and financial reporting in corporate governance and contracting. Journal of Accounting and Economics, 50, 179-234. http://dx.doi.org/10.1016/j.jacceco.2010.10.001

Bae, K., \& Goyal, V. K. (2009). Creditor rights, enforcement, and bank loans. Journal of Finance, 84, 823-860. http://dx.doi.org/10.1111/j.1540-6261.2009.01450.x

Bharath, S. T., Sunder, J., \& Sunder S. V. (2008). Accounting quality and debt contracting. The Accounting Review, 83(1), 1-28. http://dx.doi.org/10.2308/accr.2008.83.1.1

Benston, G., \& Smith, C. (1976). A transactions cost approach of the theory of financial intermediation. Journal of Finance, 31(2), 215-231. http://dx.doi.org/10.2307/2326596

Botosan, C. (1997). Disclosure level on the cost of equity capital. The Accounting Review, 72, 323-349.

Botosan, C., \& Plumlee, M. (2002). A re-examination of disclosure level and the expected cost of equity capital. Journal of Accounting Research, 40, 21-40. http://dx.doi.org/10.1111/1475-679X.00037

Diamond, D. W. (2004). Committing to commit: Short-term debt when enforcement is costly. Journal of Finance, 59(4), 1447-1480. http://dx.doi.org/10.1111/j.1540-6261.2004.00669.x

Fama, E. (1985). What's different about banks? Journal of Monetary Economics, 15(1), 247-277. http://dx.doi.org/10.1016/0304-3932(85)90051-0

Francis, B., Hasan, I. \& Song, L. (2012). Are firm- and country-specific governance substitutes? Evidence from financial contracts in emerging markets. Journal of Financial Research, 35(3), 343-374. http://dx.doi.org/10.1111/j.1475-6803.2012.01320.x

Freixas, X., \& Rochet, J. (1997). Microeconomics of Banking. MIT Press, Cambridge, MA. 
Hasan, I., \& Song, L. (2014). Disclosure and bank loan contracting: Evidence from emerging markets. Asian Review of Accounting. In Press. http://dx.doi.org/10.1108/ARA-10-2013-0069

Klapper, L. F., \& Love, I. (2004). Corporate governance, investor protection, and performance in emerging markets. Journal of Corporate Finance, 10, 703-728. http://dx.doi.org/10.1016/S0929-1199(03)00046-4

Jappelli, T., \& Pagano, M. (1993). Information sharing in credit markets. Journal of Finance. 48(5), 1693-1718. http://dx.doi.org/10.1111/j.1540-6261.1993.tb05125.x

Mazumdar, S. C., \& Sengupta, P. (2005). Disclosure and the loan spread on private debt. Financial Analysts Journal, 61(3), 83-95. http://dx.doi.org/10.2469/faj.v61.n3.2731

Qian, J., \& Strahan, P. (2007). How laws and institutions shape financial contracts: The case of bank loans. Journal of Finance, 62(6), 2803-2834. http://dx.doi.org/10.1111/j.1540-6261.2007.01293.x

Strahan, P. E. (1999). Borrower risk and the price and nonprice terms of bank loans. FRB of New York Staff Report No. 90.

\section{Appendix}

\begin{tabular}{|l|l|}
\hline \multicolumn{1}{|c|}{ Variable } & \multicolumn{1}{c|}{ Description } \\
\hline Company_Disclosure & $\begin{array}{l}\text { The total value of the answers to the questions in the } \\
\text { transparency category of the CLSA survey. }\end{array}$ \\
\hline Company_Size & The logarithm of total assets. \\
\hline Size_Dummy & $\begin{array}{l}\text { One if a company has more than the median value of } \\
\text { Company_Size and zero otherwise. }\end{array}$ \\
\hline Company_Leverage & Total liability scaled by total assets. \\
\hline Leverage_Dummy & $\begin{array}{l}\text { One if a company has more than the median value of } \\
\text { Company_Leverage and zero otherwise. }\end{array}$ \\
\hline Company_Profitability & Earnings scaled by total assets. \\
\hline Profitability_Dummy & $\begin{array}{l}\text { One if a company has more than the median value of } \\
\text { Company_Profitability and zero otherwise. }\end{array}$ \\
\hline Company_Tangibility & PP\&E scaled by total assets. \\
\hline Tangibility_Dummy & $\begin{array}{l}\text { One if a company has more than the median value of } \\
\text { Company_Tangibility and zero otherwise. }\end{array}$ \\
\hline Company_Diversification & $\begin{array}{l}\text { One if a company has more than one segment and zero } \\
\text { otherwise. }\end{array}$ \\
\hline Diversification_Dummy & $\begin{array}{l}\text { One if Company_Diversification is equal to one and zero } \\
\text { otherwise. }\end{array}$ \\
\hline Company_Maturity & The number of years since their IPO. \\
\hline Maturity_Dummy & $\begin{array}{l}\text { One if a company has more than the median value of } \\
\text { Company_Maturity and zero otherwise. }\end{array}$ \\
\hline Company_Lending_Relationship & The logarithm of (1+ the number of previous borrowing). \\
\hline
\end{tabular}




\begin{tabular}{|l|l|}
\hline Lending_Relationship_Dummy & $\begin{array}{l}\text { One if a company has more than the median value of } \\
\text { Company_Lending_Relationship and zero otherwise. }\end{array}$ \\
\hline Conpany_Governance & $\begin{array}{l}\text { The average value of the answers to the questions in the } \\
\text { management discipline, independence, accountability, } \\
\text { responsibility, and fairness categories of the CLSA survey. }\end{array}$ \\
\hline Country_Investor_Protection & The average value of the world governance index. \\
\hline Country_GDP_Growth & Change in GDP per capita. \\
\hline Bank_Loan_Size & Loan amount. \\
\hline Bank_Loan_Maturity & Loan maturity. \\
\hline Bank_Loan_Spread & Loan spread. \\
\hline Bank_Loan_Type_Dummy & Dummy variables for each type of loan. \\
\hline Industry_Dummy & Dummy variables for each industry. \\
\hline Year_Dummy & Dummy variables for each year. \\
\hline
\end{tabular}

\section{Copyright Disclaimer}

Copyright for this article is retained by the author(s), with first publication rights granted to the journal.

This is an open-access article distributed under the terms and conditions of the Creative Commons Attribution license (http://creativecommons.org/licenses/by/3.0/). 